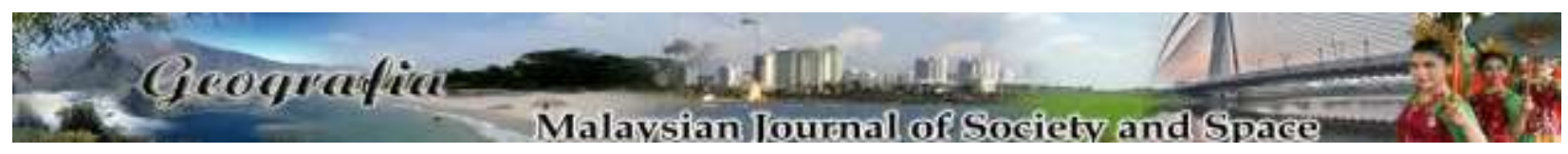

\title{
Analisis konflik masyarakat tempatan dalam satu kajian kes perkongsian dengan syarikat di Peranap, Riau, Indonesia
}

\author{
Adli Hirzan, Mimi Hanida Abdul Mutalib \\ Program Antropologi dan Sosiologi, Pusat Kajian Pembangunan, Sosial dan Persekitaran, \\ Universiti Kebangsaan Malaysia
}

Correspondence: Mimi Hanida Abdul Mutalib (email: mimi8ab@ukm.edu.my)

Received: 19 December 2019; Accepted: 06 August 2020; Published: 28 August 2020

\begin{abstract}
Abstrak
Provinsi Riau adalah sebuah provinsi perladangan kelapa sawit yang terbesar di Indonesia dan telah menarik minat para pelabur perladangan. Perihal aktiviti pelaburan dalam sektor perladangan kelapa sawit jika tidak benar-benar diatur dalam undang-udang mampu menimbulkan konflik serta merugikan masyarakat tempatan dan turut memberikan kesan buruk kepada masyarakat adat yang memiliki tanah komunal. Konflik agraria di sektor perladangan pada tahun 2018 adalah yang tertinggi berbanding sektor lainnya dan terjadi pada perladangan kelapa sawit di Provinsi Riau. Kajian ini bertujuan untuk mengenal pasti bentuk konflik yang telah terjadi di antara masyarakat tempatan dan pelabur perkebunan. Kajian ini dilakukan di Peranap kerana kawasan ini memiliki masyarakat tempatan yang masih mempunyai tanah komunal. Pemilihan informan kajian dilakukan dengan pensampelan bertujuan berasaskan kriteria tertentu iaitu tokoh masyarakat, syarikat dan pemerintah tempatan dengan semuanya berjumlah 14 orang. Jenis kajian ini adalah kajian kes dengan menggunakan kaedah pendekatan kualitatif. Hasil penemuan kajian menunjukkan bahawa konflik terjadi semasa perkongsian antara koperasi dan syarikat, konflik dalam koperasi, konflik pemberian pampasan tidak berbaloi, dan konflik pembangunan perladangan syarikat yang mengambil tanah masyarakat. Hasil daripada analisis tema yang dijalankan, kajian ini menunjukkan ada 3 konflik yang terjadi pada koperasi iaitu pembuatan senarai petani plasma tidak sesuai, penyalahgunaan pembahagian keuntungan daripada syarikat, dan perebutan pengurusan koperasi.
\end{abstract}

Kata kunci: kes perkongsian, konflik tanah, masyarakat tempatan, perladangan kelapa sawit, sosiologi pendesaan, tanah komunal 


\title{
Analysis of local community conflict in a case study of partnerships with company in Peranap, Riau, Indonesia
}

\begin{abstract}
Riau Province is a province of the largest oil palm plantation in Indonesia and attracted many plantation investors. However, the investment activities on oil palm plantations, if not correctly regulated is capable of causing conflict and harm to the local community and also brings adverse effects to the indigenous people who are owning the communal land. Thus, the agrarian conflict on the plantation sector in 2018 was the highest compared to other sectors and occurred on palmoil plantations in Riau Province. This study aims to identify forms of conflict that have occurred between local communities and plantation investors. The study was conducted in Peranap District because this area has a local community who still have communal land. The selection of informant was done by purposive sampling based on specific criteria, namely local community leaders, companies, and local governments, with a total of 14 informant. The type of study is a case study using a qualitative approach method. The results of this study show that conflict has arisen during the partnership between cooperatives and the company, the internal conflict in the cooperatives, the company compensation that not worth it, and the conflict of company plantation development that takes over the community land. The result from the thematic analysis shows that there are three conflicts in the cooperative, namely, the creation of the plasma farmers list is inappropriate, the abuse of profit-sharing from the company, and also there are power struggle in the cooperative management.
\end{abstract}

Keywords: partnership case, land conflict, local communities, oil palm plantation, rural sociology, communal land

\section{Pengenalan}

Undang-undang pokok agraria telah dibuat pada pertama kalinya pada 1960. Undang-undang ini dibuat untuk mengatur pemberian kuasa oleh negara dalam mengawal tanah yang terletak di Indonesia. Hak kawalan daripada negara menentukan adanya pelbagai jenis hak ke atas permukaan bumi yang disebut tanah. Hak ini boleh diberikan kepada dan dimiliki oleh orangorang, baik persendirian mahupun bersama-sama dengan orang lain dan entiti undang-undang. Semua hak ke atas tanah mempunyai fungsi sosial (social function). Kebanyakan syarikat tidak memberikan kepentingan fungsi terhadap pemberian hak ke atas tanah. Undang-undang ini wujud dengan menekankan bahawa fungsi sosial mesti dijalankan bersamaan dengan pemberian hak ke atas tanah. Fungsi sosial di sini bermaksud agar syarikat wajib menjaga kesejahteraan masyarakat yang ada di persekitaran tanah dan berguna untuk mengelakkan terciptanya sistem kapitalisme. Pemerolehan keuntungan secara besar-besaran adalah dibenarkan bagaimanapun, tidak sekali-kali meminggirkan atau mengenepikan kepentingan awam masyarakat tempatan yang sedia ada.

Walaupun undang-undang pokok agraria telah wujud sekian lama untuk mengatur segala perkara tentang tanah, namun undang-undang tersebut masih dirasai belum begitu berjaya menyelesaikan konflik tanah. Berdasarkan data NGO dalam Rekod Akhir Tahun KPA, 
sepanjang tahun 2018 sekurang-kurangnya wujud 410 konflik daerah yang mencakupi kawasan seluas 807,177,613 hektar. Setakat ini, Konsortium Pembaharuan Agraria (KPA) merekodkan konflik tanah di Indonesia sepanjang tahun 2018 kebanyakannya di sektor perladangan sebanyak 73\% dari kawasan luas konflik tanah atau seluas 591,640.32 hektar.

Berdasarkan Rajah 1, konflik tanah di sektor perladangan pada tahun 2018 telah mewujudkan sebanyak 144 kes (35 peratus) dalam kes yang tertinggi. Sebanyak 83 kes (60 peratus) daripada 144 konflik tanah itu terjadi di perladangan kelapa sawit. Dalam tahun 2018, selain sektor perladangan, konflik tanah yang paling tinggi berlaku di sektor hartanah dengan 137 kes (33 peratus). Ini diikuti konflik tanah dalam sektor pertanian (53 konflik atau 13 peratus), sektor perlombongan ( 29 konflik atau 7 peratus), sektor perhutanan (19 konflik atau 5 peratus), infrastruktur (16 konflik atau 4 peratus), dan sektor pesisir (12 konflik atau 3 peratus). Berdasarkan catatan KPA, 410 kes pada tahun lepas melengkapkan bilangan konflik tanah yang berlaku dalam tiga tahun semasa pemerintahan presiden Jokowi-Jusuf Kalla (2015-2018) menjadi 1.769 .

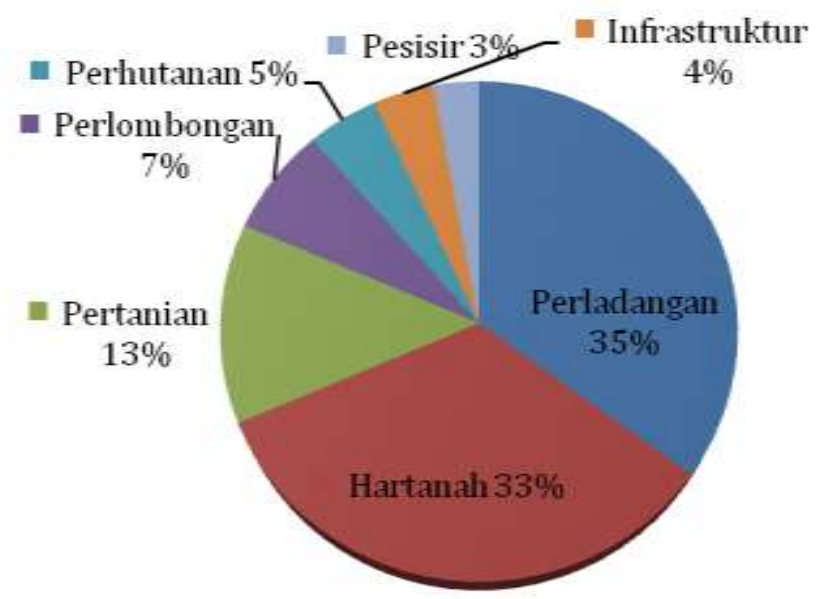

- Perladangan
= Hartanah
= Pertanian
= Perlombongan
- Perhutanan
= Infrastruktur
= Pesisir

Sumber: Rekod Akhir Tahun 2018 Konsortium Pembaharuan Agraria

Rajah 1. Taburan konflik tanah dalam pelbagai sektor di Indonesia berdasarkan jumlah kes tahun 2018

Sepanjang tahun 2018, letusan konflik tanah terjadi di 444 buah kampung dan 200 buah bandar. Terdapat 10 wilayah provinsi terjadinya konflik tanah tertinggi pada tahun 2018, di antaranya ialah wilayah Riau, Jawa Timur, Sumatera Selatan, Jawa Barat, Lampung, Sumatera Utara, Banten, Aceh, Kalimantan Tengah, dan DKI Jakarta. Pada peringkat pertama, sebanyak 42 kes konflik tanah terjadi di Riau. Sementara di Jawa Timur terdapat 35 dan 28 konflik berlaku di Sumatera Selatan dan Jawa Barat. Dari 10 wilayah besar yang berlaku konflik sepanjang tahun 2018, lima wilayah yang mempunyai kedudukan tertinggi dalam menyumbang konflik tanah masih konsisten seperti pada tahun 2017 di mana penyumbang terbesar konflik tanah ialah Provinsi Riau, Jawa Timur, Jawa Barat, Sumatera Utara, dan Lampung. Ini menandakan konsistensi dari 5 daerah besar yang turut menyumbang kepada konflik tanah sama ada konflik di wilayah ini tidak mengalami penurunan yang bererti. Jadual 1 menunjukkan tiga provinsi yang mengalami konflik tanah teratas dalam 5 tahun terakhir mulai dari tahun 2014 hingga 2018. 
GEOGRAFIA Online ${ }^{\mathrm{TM}}$ Malaysian Journal of Society and Space 16 issue 3 (167-183)

(C) 2020, e-ISSN 2682-7727 https://doi.org/10.17576/geo-2020-1603-13

Jadual 1. Tiga dari lima provinsi yang mengalami konflik tanah teratas dalam lima tahun terakhir tempoh 2014-2018

\begin{tabular}{|c|c|c|c|c|c|}
\hline Provinsi & 2014 & 2015 & 2016 & 2017 & 2018 \\
\hline Riau & $52-[1]$ & $36-[1]$ & $44-[1]$ & $47-[4]$ & $42-[1]$ \\
\hline Jawa Timur & $44-[2]$ & $34-[2]$ & $43-[2]$ & $60-[1]$ & $35-[2]$ \\
\hline Jawa Barat & $39-[3]$ & $15-[5]$ & $38-[5]$ & $55-[2]$ & $28-[4]$ \\
\hline
\end{tabular}

[ ] = peringkat

Sumber : Rekod Akhir Tahun 2018 Konsorsium Pembaharuan Agraria

Merujuk kepada jadual 1, daripada tiga wilayah yang memiliki konflik terbanyak, Provinsi Riau terletak di peringkat pertama. Di Riau menerusi laporan akhbar oleh (Anwar Tanjung, 2017) penyiasatan pihak DPRD (legislatif wilayah) Riau, didapati bahawa perladangan sawit mencapai dalam 4.2 juta hektar (ha). Daripada hasil carian, diperoleh perladangan sawit haram di Riau mencapai dalam 1.8 juta hektar dan status perladangan sawit tidak mempunyai lesen pembebasan kawasan hutan dari Kementerian Alam Sekitar dan Perhutanan. Perladangan kelapa sawit merangkumi kawasan hutan termasuk kawasan hutan lindung, rizab hidupan liar serta taman negara. Perladangan sawit haram ini terdapat peringkat umurnya yang sudah ditanam semula (re-planting). Maksudnya, penanaman sawit di kawasan ini sudah ada yang mencapai usia 30 tahun dan sebahagiannya berumur 15 tahun, 9 tahun dan 5 tahun. Fakta ini menunjukkan bahawa sudah bertahun-tahun dekad perladangan sawit haram ini ditubuhkan tanpa perlesenan yang sah. Selain itu, konflik tidak hanya berlaku pada syarikat-syarikat perladangan sawit yang mempunyai perlesenan secara haram, tetapi juga turut memberikan kesan buruk kepada masyarakat adat yang memiliki tanah persendirian. Merujuk kepada Azima bahawa tanah adat bukan sahaja menjadi berharga dalam nilai ekonomi masyarakat melainkan juga sebagai identiti masyarakat adat sehingga dalam kalangan masyarakat adat ada yang berpendapat tanpa tanah adat dan identiti suku, kehidupan mereka tidak boleh diteruskan (Abdul Manaf et al., 2015).

Dalam kajian ini, pengkaji berfokus kepada masalah perladangan kelapa sawit di salah sebuah kabupaten yang ada di Provinsi Riau iaitu Kabupaten Indragiri Hulu. Ada tiga syarikat yang berstatus sendirian berhad dan wujud konflik di kabupaten ini iaitu syarikat Runggu Prima Jaya (RPJ), Bagas Indah Perkasa (BIP), dan Bintang Riau Sejahtera (BRS). Satu syarikat yang menjadi fokus utama ialah syarikat Bintang Riau Sejahtera. Syarikat ini diketahui berusaha dalam bidang perladangan kelapa sawit dan telah bermula semenjak pelesenannya diberikan mulai tahun 2004 silam. Syarikat ini juga melakukan perkongsian (partnership) bersama masyarakat tempatan dalam berladang sawit di tanah kawasan masyarakat tempatan 4 kampung/desa iaitu Desa Baturijal Barat, Baturijal Hulu, Baturijal Hilir dan Semelinang Darat. Hal ini selari dengan keperluan undang-undang no.18/2004 tentang perladangan, bahawa syarikat perladangan harus melakukan perkongsian yang saling menguntungkan, saling menghargai, saling bertanggungjawab, saling menguatkan, dan saling bergantung dengan peladang, pekerja, dan masyarakat di persekitaran ladang.

Syarikat dapat membuat perladangan di tanah kawasan masyarakat tempatan dengan terma-terma yang berlaku iaitu dengan adanya Memorandum of Understanding (MoU) atau Memorandum Persefahaman antara Koperasi Tiga Serumpun milik masyarakat dengan syarikat Bintang Riau Sejahtera. Memorandum Persefahaman itu juga dikuatkuasakan dengan instrumen undang-undang seperti Surat Keputusan (SK) Bupati no. 154/2008 tentang penetapan calon petani dan calon lahan (CP-CL) program revitalisasi perladangan bersama syarikat di 4 kampung tersebut. Syarikat ini mendapatkan perlesenan Hak Guna Usaha seluas 4250 hektar dengan terma bahawa syarikat juga harus membangunkan perladangan plasma untuk masyarakat tempatan 
seluas $40 \%$ daripada luas ladang milik syarikat. Sementara itu, pembiayaan (cost) dalam membangunkan perladangan untuk masyarakat tempatan berasal daripada $20 \%$ keuntungan perladangan syarikat. Namun semasa operasinya, syarikat Bintang Riau Sejahtera telah mengalami konflik dengan masyarakat tempatan semenjak syarikat ini selesai membangunkan kebun kelapa sawit pada tahun 2006. Konflik ini berlaku disebabkan syarikat tidak memenuhi kewajipannya kepada masyarakat untuk membina kebun plasma sesuai dengan janjinya. Konflik ini juga mewujudkan konflik-konflik lain yang sangat kompleks. Maka untuk memahami konflik yang sebenar perlu melihat realiti yang terjadi di antara masyarakat tempatan dan syarikat pelabur perkebunan. Justeru, artikel ini bertujuan untuk mengenal pasti bentuk-bentuk konflik yang terjadi di antara masyarakat tempatan 4 kampung di kawasan Indragiri Hulu, Riau dan syarikat perladangan kelapa sawit dalam satu kes perkongsian.

\section{Kajian literatur}

Sulistianawati dalam (Kospa, 2016) menerangkan bahawa corak inti-plasma menurut undangundang no. 9/1995 adalah "hubungan perkongsian antara perniagaan kecil dengan perniagaan menengah atau besar sebagai usaha untuk membina dan membangunkan perniagaan kecil yang menjadi plasmanya melalui penyediaan tanah, kemudahan pengeluaran, memberi bimbingan teknikal pengurusan perniagaan dan pengeluaran, pemerolehan penguasaan dan peningkatan teknologi yang diperlukan". Corak kerjasama perkongsian inti-plasma dengan pemilikan tanah oleh petani, pada amnya dengan corak kerjasama pembahagian keuntungan (profit). Petani menyerahkan seluruh tanah kepada syarikat ini untuk mendapatkan hak guna usaha (The Cultivation Rights Title) dan sebagai balasannya, petani mendapatkan pembahagian keuntungan 20\% dari jumlah keuntungan syarikat kebun kelapa sawit (Kospa, 2016).

Faktor konflik sosial yang berpunca daripada perubahan struktur sosioekonomi masyarakat dari sistem perladangan tradisional (subsistence) ke atas pengurusan potensi kekayaan sumber asli kepada sistem perindustrian oleh kapitalis menerusi corak ladang syarikat dan kebun plasma, sehingga mewujudkan kumpulan masyarakat di atas struktur sumber asli meliputi kumpulan yang mempunyai kuasa sumber ekonomi (kapitalisme) dan kumpulan yang mempunyai kuasa sumber sosial (masyarakat) (Arkanudin \& Rupita, 2020; Chrisnawan, 2016; Sobri, 2017; Thomas, Sikwan, \& Rahmaniah, 2015)

Menurut Yunus (2013), konflik banyak terjadi kerana disebabkan oleh isu persekitaran, pertindihan tanah, sempadan wilayah, dan paling banyak adalah isu kewajipan atau perjanjian syarikat yang tidak dipenuhi kepada masyarakat serta perebutan tanah masyarakat oleh syarikat swasta. Menurut Mutolib, Yonariza, Mahdi, \& Ismono (2015), konflik pertanian juga berlaku kerana saling mendakwa di antara masyarakat dan kerajaan untuk pemilikan hutan. Masyarakat mendakwa taman negara yang kebenaran pengurusannya diberikan kepada syarikat sebagai tanah persendirian masyarakat adat yang telah diduduki selama beratus-ratus tahun. Isu sumber daya hutan lainnya juga boleh berlaku bergantung kepada tafsiran peraturan bertindih di sektor perhutanan. Tanggapan entiti pemerintah dan perniagaan swasta di sektor perhutanan mengenai kewujudan masyarakat di sekitar hutan serta juga keadaan sejarahnya yang berbeza dalam pengurusan hutan di Jawa dan luar Jawa (Surono, 2016). 


\section{Metod dan kawasan kajian}

Penyelidikan ini dijalankan di daerah Peranap yang secara amnya terbahagi kepada 12 buah kawasan kampung (Rajah 2). Daripada 12 wilayah ini, kebanyakannya konflik berlaku di kebun kelapa sawit, tetapi pengkaji hanya akan memfokuskan kepada satu syarikat yang telah mengalami konflik selama beberapa tahun dengan masyarakat adat yang juga dikenali sebagai masyarakat "Tiga Lorong" yang merangkumi empat kawasan iaitu Kampung Baturijal Hilir, Kampung Baturijal Barat, Kampung Baturijal Hulu dan Kampung Semelinang Darat (Rahman, Syam, \& Mardan, 2013).

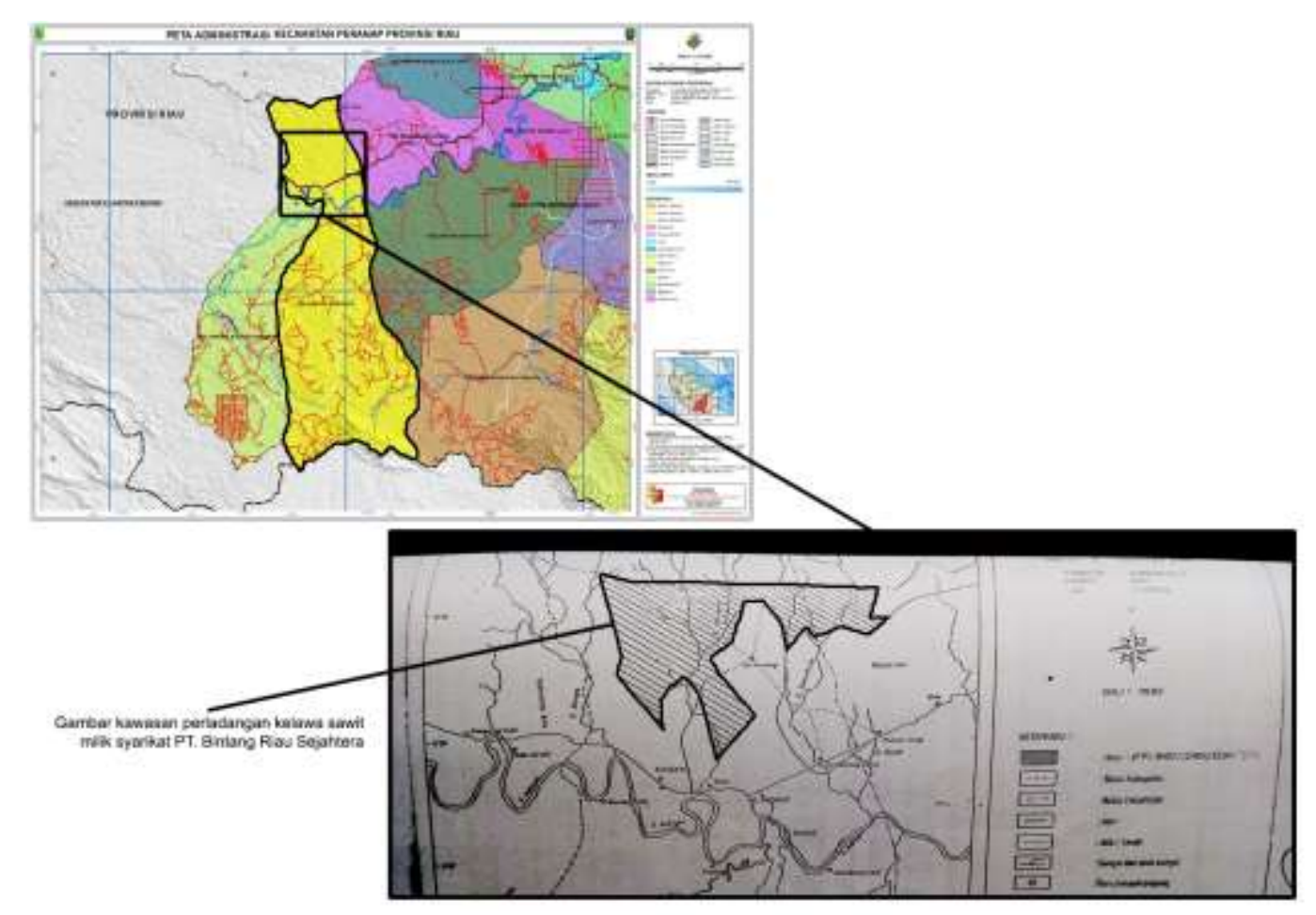

Sumber: petatematikindo dan dokumen penyelidik, 2019

Rajah 2. Peta daerah Peranap dan kawasan perladangan syarikat PT. Bintang Riau Sejahtera

Kajian ini menggunakan pendekatan kualitatif dalam mengenal pasti keadaan konflik masyarakat 4 kawasan kampung dengan syarikat swasta. Creswell (2003) menyatakan bahawa penyelidikan secara kualitatif digunakan untuk meneroka, memahami, dan mentafsirkan secara hati-hati kepada satu makna yang berbeza daripada kefahaman biasa. Selanjutnya, menurut Strauss dan Corbin (dalam Creswell, 1998), penyelidikan kualitatif adalah jenis penyelidikan yang menghasilkan penemuan-penemuan yang tidak boleh diperoleh dengan kaedah statistik atau cara-cara lain daripada kuantifikasi (pengukuran). Pelbagai jenis reka bentuk penyelidikan kualitatif yang boleh ditawarkan, tetapi kajian ini akan menggunakan pendekatan kajian kes. Menurut Stake (dalam Creswell, 2003), kajian kes adalah di mana penyelidik meneroka secara mendalam pada satu program, peristiwa, aktiviti, proses, atau lebih dari satu individu. Penyelidik mesti menghabiskan masa di lokasi, lalu berinteraksi dengan informan kajian. Pelbagai kajian kes telah berjaya dilakukan dengan menggunakan pendekatan kualitatif, seperti kajian Setyawan (2012) mengemukakan konflik tanah pastinya membabitkan petani, pegawai perhutanan, 
pegawai pemerintahan dan syarikat swasta. Sementara itu, kajian Effendi, Arif Nasution, Hamdani Harahap, dan Amin, (2018) mengemukakan bahawa faktor ekonomi membuat ketua kampung menjual tanah komunal tanpa mesyuarat dengan masyarakat dan juga tanpa diberi pampasannya.

Pemilihan informan kajian dilakukan dengan kaedah persampelan bertujuan. Menurut Chua (2012), subjek pada persampelan bertujuan yang mempunyai ciri-ciri tertentu sahaja dipilih untuk dijadikan sebagai informan, dan bukan semua populasi berpeluang dijadikan informan. Pemilihan informan kajian dilakukan dengan persampelan bertujuan berasaskan kriteria tertentu iaitu tokoh masyarakat, syarikat dan pemerintah tempatan dengan semuanya berjumlah 14 orang. Terdapat kaedah pengumpulan data yang berbeza untuk penyelidikan kualitatif. Data kajian kes diambil dalam pelbagai bentuk seperti; (1) dokumentasi surat, memorandum persefahaman, agenda, laporan mesyuarat; (2) rekod arkib perkhidmatan, data tinjauan, peta, senarai nama; (3) temu bual yang dilakukan dengan cara tidak berstruktur kerana kaedah ini boleh menawarkan keanjalan, spontan, dan tindak balas yang berbeza mengikut individu serta situasi; (4) pemerhatian langsung (Yin, 1989). Pada kes kajian ini, penyelidik menggunakan kaedah analisis tematik. Braun \& Clarke (dalam Heriyanto, 2018) menyatakan analisis tematik adalah satu cara untuk menganalisis data dengan matlamat mengenal pasti corak atau untuk mencari tema melalui data yang telah dikumpulkan oleh penyelidik. Fereday dan Muir-Cochrane (dalam Heriyanto, 2018) juga menyatakan, kaedah ini adalah kaedah yang sangat berkesan jika satu kajian bermaksud untuk meneroka secara terperinci data kualitatif yang dimiliki dan mencari kaitan corak dalam satu fenomena serta juga menjelaskan sejauh mana satu fenomena itu berlaku melalui lensa penyelidik.

\section{Hasil kajian dan perbincangan}

\section{Konflik perkongsian perladangan inti syarikat dan plasma masyarakat}

Selain Undang-Undang (UU) Republik Indonesia no. 9 tahun 1995 mengenai perniagaan kecil menjelaskan tentang perkongsian, prosedur untuk menjalankan perkongsian termaktub dalam peraturan kerajaan Indonesia no. 44 tahun 1997 mengenai perkongsian. Dalam sistem intiplasma, Syarikat Besar atau Syarikat Sederhana sebagai panduan teras dalam membimbing dan membangunkan perniagaan kecil dalam penyediaan tanah, kemudahan pengeluaran, panduan teknikal untuk pengurusan perniagaan pengeluaran, pengambil alihan, penguasaan dan peningkatan teknologi yang diperlukan, pembiayaan dan penyediaan bantuan lain yang diperlukan untuk meningkatkan kecekapan dan produktiviti perniagaan.

Kedua-dua peraturan yang wujud di negara Indonesia ini menjadi satu penekanan bahawa syarikat besar diharuskan untuk menjalankan perkongsian dengan peniaga kecil seperti dalam kes kajian ini adalah syarikat PT. BRS dengan koperasi Tiga Serumpun. Pada 16 November tahun 2006 bertempat di pejabat mukim Peranap bersetuju dengan memorandum persefahaman antara Koperasi Tiga Serumpun mukim Peranap mewakili masyarakat Kampung Baturijal Barat, Baturijal Hulu, Semelinang Darat dan Baturijal Hilir dengan syarikat mengenai sistem pembangunan perkongsian kebun kelapa sawit. Untuk memahami lebih dalam isi kandungan memorandum persefahaman, boleh melihat ringkasannya di bawah: 
"Para pihak bersetuju untuk mengadakan kerjasama sistem perkongsian pembangunan kebun kelapa sawit dengan terma dan syarat seperti kerjasama dalam membangunkan perkongsian untuk mengurus dan membangunkan kelapa sawit di atas tanah seluas 4.520 hektar dengan pembahagian $60 \%$ atau 2.712 hektar untuk kebun inti dan $40 \%$ atau 1.808 hektar untuk kebun plasma. Mereka bersetuju juga untuk bekerjasama dalam tempoh masa 27 tahun atau sehingga tanaman tidak mempunyai nilai ekonomi lagi dan boleh dilanjutkan lagi." (dalam dokumen memorandum persefahaman antara Koperasi Tiga Serumpun dengan syarikat Bintang Riau Sejahtera, 2006).

Selepas perkongsian antara masyarakat dengan syarikat terdapat banyak konflik yang muncul dalam kalangan mereka di antaranya:

a. Ketidakseriusan syarikat dalam membina kebun plasma masyarakat

Pihak syarikat membina kebun kelapa sawit plasma yang pada perjanjian awalnya seluas 1808 hektar diubah menjadi dua kawasan Plasma A dan B, iaitu untuk tanah seluas lebih kurang 325 hektar terletak di sebelah utara ladang syarikat yang bersepadan dengan syarikat lain, dan tanah seluas kurang lebih 126 hektar yang terletak di kiri-kanan jalan masuk ke ladang syarikat yang telah diserahkan oleh masyarakat kepada syarikat tanpa pampasan. Pada Disember 2012, mesyuarat diadakan di pejabat agensi kerajaan Perladangan Daerah Indragiri Hulu mengenai dakwaan koperasi Tiga Serumpun kepada syarikat.

"PT. BRS akan memperuntukkan kebun plasma kepada Koperasi Tiga Serumpun seluas 20\% (241 hektar) daripada luas kebun inti yang hanya diperoleh seluas 1203,13 hektar." (dalam dokumen minit hasil mesyuarat PT. BRS dengan Koperasi)

Dari hasil dokumen minit di atas dapat dijelaskan bahawa syarikat akan membangunkan lagi kebun plasma seluas 241 hektar di luar plasma A dan B. Persoalan terjadi ketika tanah seluas 126 hektar yang dianggap sebagai plasma A tidak dapat dibina dengan baik oleh syarikat dan juga persoalan lain terjadi di kawasan seluas 600 hektar yang dibina oleh syarikat untuk kebun plasma itu terletak di ladang syarikat lain iaitu PT. RPI.

"pernah saya ajukan plasma B yang berupa tanah masyarakat. Plasma ini untuk menambah kebun plasma yang akan dibagikan kepada masyarakat. Plasma ini dibuat karena perusahaan takut didemo oleh masyarakat. Jadi perusahaan membujuk dengan mengganti plasma di atas yang tidak selesai." (Encik Edi Suhardi, 2019)

Menurut kutipan informan di atas, Ketua kampung Baturijal Hulu tahun 2007-2013 bersama masyarakat mencadangkan plasma B kepada syarikat iaitu tanah daripada milik masingmasing masyarakat yang ada di sepanjang laluan masuk perladangan inti syarikat sampai ke 
laluan awam. Plasma ini sebagai hadiah untuk masyarakat yang tidak mendapatkan plasma di utara (Plasma A) dan juga bermatlamat untuk menambahkan jumlah kebun plasma yang akan dibahagikan kepada masyarakat. Plasma yang berada di bawah atau selatan seluas 126 hektar (Plasma B) juga dibangunkan kerana ingin mengelakkan demonstrasi oleh masyarakat empat kampung ini kepada syarikat. Syarikat bermaksud ingin memujuk masyarakat dengan membuat penggantian plasma di atas yang belum selesai dibina, dengan membuat plasma $\mathrm{B}$ yang juga permintaan daripada masyarakat. Akhirnya, hasil dari pembinaan plasma B juga tidak selesai kerana dari luas 126 hektar, syarikat hanya boleh membina seluas 80 hektar sahaja dan kualiti pembinaan kebun plasma masyarakat tidak sama dengan pembinaan ladang syarikat.

\section{b. Kesilapan pengiktirafan letak kebun plasma masyarakat}

Perkara mengenai lokasi kebun plasma masyarakat adalah terjadi perdebatan berkenaan letak kebun plasma.

"Sekitar 400 hektar sudah kami sediakan. Setelah saya bertukar dengan pengurus yang baru, dia tidak menerima lahan yang telah kami siapkan. Dia mau mengambil lahan inti tadi. Perusahaan tentu tidak mau kebun inti diganggu. Jadi akhirnya gagal bermitra dan kebunpun kembali lagi ke masing-masing masyarakat." (Encik Edi Suhardi dan Haryanto, 2019)

Merujuk petikan di atas, syarikat tidak ingin perladangan mereka diganggu dengan wujudnya kebun plasma masyarakat di kawasan perladangan syarikat. Namun sebaliknya, pengurus koperasi kedua tahun 2012-2014 menganggap bahawa kebun plasma itu berada di dalam HGU dan tidak mengakui plasma berada di luar perladangan syarikat PT. BRS. Sehingga tanah yang telah dikumpulkan dan disediakan oleh masyarakat harus dipulangkan semula kepada masyarakat serta perjanjian kerjasama pembangunan plasma oleh syarikat menjadi terkekang. Jadi, tanah bakal kebun plasma dikembalikan kepada pemiliknya masing-masing menurut dokumen atau perakuan pemilikan. Sikap pengurus koperasi kedua ini sangat bertentangan dengan undang-undang no. 98 tahun 2013 pasal 15 ayat 2 bahawa kebun plasma masyarakat berada di luar kawasan perladangan syarikat.

\section{Konflik koperasi}

Penubuhan koperasi harus digunakan sebagai satu wadah yang mempunyai badan perundangan bagi menampung masyarakat yang berkongsi dengan syarikat perladangan. Merujuk kepada keputusan Menteri Pertanian no. 357 tahun 2002 tentang panduan undang-undang mengusahakan perladangan pada pasal 19 ayat 1 huruf $\mathrm{F}$ iaitu syarikat perladangan yang telah memperoleh perlesenan perladangan perlulah membangun dan membina masyarakat atau koperasi tempatan.

Merujuk kepada keputusan Menteri Pertanian di atas maka ia menjadi asas penubuhan koperasi Tiga Serumpun yang akan menjadi tempat di mana masyarakat dengan syarikat saling berkongsi pada 16 Julai 2005. Pada tahun 2006, satu kerjasama dibuat dengan memorandum persefahaman antara koperasi Tiga Serumpun mewakili masyarakat empat kampung dengan 
syarikat PT. BRS mengenai corak sistem pembangunan kebun kelapa sawit inti-plasma. Penubuhan koperasi sebagai badan atau tempat bagi masyarakat berkongsi dengan syarikat telah mengalami pelbagai konflik, di antaranya:

a. Pembuatan senarai nama petani plasma yang salah

Pada 1 Januari 2013, satu mesyuarat pemerintah dari empat kampung di bilik ketua agensi kerajaan perladangan daerah Indragiri Hulu untuk mengkaji semula tentang senarai nama calon petani plasma yang berkongsi dengan syarikat PT. BRS yang dihantarkan oleh pengurus koperasi Tiga Serumpun tahun 2012 hingga 2014 kerana tidak sesuai dengan keadaan sebenar (dalam dokumen surat kepada ketua agensi perkebunan berkenaan nama calon petani plasma yang dikemukakan pengurus kedua koperasi, 2013). Selepas itu, pemerintah empat kampung ini tidak bersetuju sebab pemilik tanah yang bernama ini sudah diberi ganti rugi oleh syarikat dan terdapat juga nama yang tidak memiliki tanah.

"waktu masa saya dulu dibagi rata. Kemudian ada yang berkebun disana, kebunnya diganti oleh perusahaan. Diutamakan orang yang tak dapat ganti rugi untuk namanya dimasukkan ke dalam calon petani." (Encik Haryanto, 2019)

Menurut petikan informan di atas, banyak tanah masyarakat yang telah diagihkan kepada syarikat dan tidak meminta ganti rugi selagi mereka memperoleh kebun plasma. Syarikat itu bersedia dan memberi jaminan menerusi surat kebenaran dari koperasi. Beberapa tanah masyarakat telah diberi pampasan oleh syarikat, tetapi pengagihan plasma diutamakan untuk masyarakat yang tidak mendapat ganti rugi.

"masalah CP-CL waktu itu, Pak Sutia pernah memasukkan orang yang tidak menetap di kampung dan tidak ada lahan disana. Sedangkan masyarakat banyak belum mendapat. Sebab ingin mendapatkan kembali lahan yang Pak Sutia pernah serahkan ke perusahaan 60 hektar. Ketahuan ketika ada masyarakat mendapatkan fotokopi CP-CL." (Encik Edi Suhardi, Rais, dan Rasmizon, 2019)

Merujuk petikan 3 informan di atas, setiausaha koperasi yang kedua memasukkan masyarakat ke dalam senarai nama bakal petani plasma yang tidak menetap di kampung ini sementara ramai nama masyarakat yang belum dimasukkan. Justeru, perkara ini dibuat kerana setiausaha pengurus koperasi kedua ingin mendapatkan semula tanahnya yang telah diserahkan kepada syarikat dan juga sudah diberi pampasan kerana setiap orang akan memperoleh dua hektar. Dapat diketahui bahawa Calon Petani-Calon Ladang (CP-CL) bermasalah semasa seorang masyarakat mendapati salinan senarai nama CP-CL. Ketua koperasi yang kedua mengaku tidak mengetahui masalah CP-CL kerana beliau tidak ada membuat penapisan mengenai sesiapa sahaja berhak memperoleh plasma. Dapat diketahui bahawa syarikat telah membayar pampasan seramai 28 orang di empat buah kampung iaitu 20 masyarakat di Kampung Baturijal Hilir, 7 masyarakat di Kampung Baturijal Hulu, dan 1 masyarakat di Kampung Semelinang Darat (dalam dokumen senarai pampasan, 2010). Pengkaji mendapati ada tiga 
dokumen surat pampasan tanah atas nama setiausaha pengurus koperasi kedua ialah Sutia dengan kawasan tanah berbeza, dengan jumlah 62.5 hektar iaitu di antaranya seluas 18.6 hektar, 40.8 hektar, dan 3.1 hektar.

b. Penyalahgunaan wang pembahagian keuntungan syarikat (rasuah)

Perjanjian dibuat semula untuk pembangunan dan pengurusan kebun kelapa sawit sistem perkongsian inti-plasma antara syarikat PT. BRS dengan pengurus koperasi Tiga Serumpun yang baharu pada 2 Disember 2013 di pejabat agensi kerajaan Perladangan. Berdasarkan perjanjian kerjasama pasal 11, terdapat pembahagian hasil daripada syarikat kepada koperasi untuk pembangunan kebun plasma, maka pada 16 April 2014 pengurus koperasi memohon pengeluaran dana perkongsian keuntungan sebanyak 20\% keuntungan daripada pengeluaran kebun inti syarikat untuk ahli koperasi yang terdapat dalam senarai CP-CL. Sebelum ini, pemimpin adat, ketua kampung serta tokoh masyarakat kampung Baturijal Hulu dan Baturijal Barat mengadakan perbincangan pada 13 April 2014. Hasil perbincangan ialah mereka bersetuju dan meminta kepada syarikat untuk menangguhkan pengeluaran pembahagian hasil keuntungan (profitsharing) kepada pengurus koperasi Tiga Serumpun, hingga ada keputusan lanjutan dari pemimpin adat dan ketua kampung (dalam dokumen hasil mesyuarat pemangku adat Baturijal 2014). Namun tanggal 22 April 2014, syarikat meminta koperasi tentang penangguhan pembahagian hasil kerana syarikat mengajukan permohonan pinjaman bank untuk pembangunan kebun inti syarikat. Sementara menunggu kelulusan dari bank, ternyata syarikat membayar wang pendahuluan pembahagian hasil sebanyak 40 juta rupiah $(\mathrm{RM} 11,450)$ kepada pengurus koperasi kedua.

"ada pengurus koperasi dulu dapatlah sejumlah duit... digunakan sendiri. Dalam laporan dibuatlah untuk membeli hal-hal keperluan koperasi. Kami menganggap itu hanya akalan saja. Tidak ada yang beres. Pengurusnya mau menang dan mengambil keuntungan sendiri. Uang tadi digunakan oleh koperasi tidak tau kemana. Tidak tepat sasaran. Pemerintah desa tidak setuju uang itu dicairkan kepada koperasi awalnya." (Encik Haryanto, Sabawaihi, dan Rusli, 2019)

Jadi menurut hasil temu bual kepada tokoh masyarakat di atas, selepas pengeluaran wang itu, ramai masyarakat yang kecewa kerana wang itu tidak dibahagikan kepada ahli koperasi yang juga ialah petani plasma. Beberapa tokoh masyarakat mengakui kebenaran masalah itu. Dalam laporan pengurus kedua, mereka mengakui menggunakan wang itu untuk membeli pelbagai keperluan koperasi. Tindakan pengurus koperasi kedua ini dimaknakan telah menyalahi undangundang dan boleh disabitkan sebagai rasuah kerana pengurus telah melakukan penyalahgunaan dana hasil perniagaan. Seharusnya wang itu digunakan untuk dibahagikan kepada masyarakat ahli koperasi atau petani plasma. 


\section{c. Perebutan dalam pengurusan koperasi}

Perebutan pengurusan Koperasi Tiga Serumpun ini dimulai semasa masyarakat 4 buah kampung mengadakan perbincangan dalam forum pemimpin adat Baturijal dan Semelinang Darat bersama pemangku adat, ketua kampung, ketua mukim, dan tokoh masyarakat lainnya pada Jun 2014 untuk menyudahi paksa pengurusan koperasi kedua tempoh 2012-2014 dan menubuhkan pengurusan Koperasi Tiga Serumpun yang ketiga (dalam dokumen forum pemangku adat Baturijal, 2014). Tindakan paksa ini dilakukan masyarakat kerana pengurus kedua ini tidak mahu dan menolak untuk diganti menerusi mesyuarat ahli koperasi (RAT).

"...pernah 40 juta habis tidak tau kemana. Ia dilengserkan karena sudah banyak punya lawan dan masyarakat banyak tidak suka." (Encik Sabawaihi dan Rasmizon, 2019)

Menurut petikan di atas, faktor utama pembubaran ini disebabkan ramai masyarakat yang kecewa atas tindakan rasuah yang dilakukan oleh pengurus koperasi kedua. Pada Ogos 2014, ketua agensi perladangan koperasi membaca surat dari pemimpin adat Baturijal dan Semelinang Darat mengenai permohonan pengesahan pengurus koperasi yang ketiga. Berdasarkan hasil keputusan ketua agensi kerajaan perladangan, ia bersetuju pengurus koperasi ketiga melanjutkan pengurusan koperasi Tiga Serumpun tahun 2014-2016 dengan syarat pengurus ketiga harus menyelesaikan segera segala urusan dengan pengurus kedua. Pengurus koperasi kedua harus menyerahkan seluruh dokumen dan aset kepada pengurus ketiga selewat-lewatnya September 2014. Akhirnya, pengurus koperasi ketiga mengadakan mesyuarat pada Mac 2015 untuk meletak jawatan dari pengurusan koperasi tempoh 2014-2016. Setelahnya, setiausaha pengurus koperasi kedua terpilih kembali sebagai ketua koperasi untuk tahun 2015-2017.

"dari tahun 2014, saya sudah menjadi ketua tetapi tidak kompak. Pengurus kedua tidak memberikan dokumen koperasi kepada saya. Sutia tidak mau mengakui saya ketua karena tidak sah. Akhirnya saya mundur." (Encik Alpian, 2019)

Merujuk kutipan di atas, perletakan jawatan ini disebabkan pengurus koperasi kedua 20122014 tidak mengiktiraf kesahihan tempoh pengurusan ketiga tahun 2014-2016 dan setiausaha koperasi kedua tahun 2012-2014 juga tidak mahu memberikan dokumen yang sah kepada pengurus baharu. Maka dalam minit mesyuarat, ketua mukim mengakui pengurusan koperasi keempat iaitu kembalinya setiausaha koperasi kedua tahun 2012-2014 sebagai ketua koperasi.

\section{Konflik pampasan yang tidak berbaloi}

Penyelesaian ke atas hak tanah juga ditegaskan oleh Keputusan Menteri Pertanian no. 357 tahun 2002 fasal 19 ayat 1 bahawa syarikat perladangan yang telah memperoleh lesen mengusahakan perladangan wajib menyelesaikan hak ke atas tanah selewat-lewatnya dua tahun selepas perlesenan dikeluarkan. Masa itu syarikat telah mengusahakan perladangan kelapa sawit dengan lesen yang diperoleh daripada ketua daerah. Sebelum syarikat datang mengusahakan perladangan kelapa sawit di tanah itu, masyarakat yang terbentuk dalam kepaduan masyarakat adat di 
kampung itu telah wujud lebih dulu sebelum negara itu wujud dan mereka mengakui tanah itu sebagai tanah adat/komunal. Maksudnya sebelum negara wujud, penghulu adat serta masyarakat adat mempunyai konsep berkenaan tanah bahawa tanah itu diperuntukkan kepada semua masyarakat yang ingin mengusahakan tanah itu dan tanah itu tidak boleh diniagakan tetapi tanah itu boleh digunakan oleh sesiapa sahaja untuk kesejahteraan masyarakat. Sementara selepas negara wujud, konsep tanah itu berubah bahawa tanah itu menjadi milik negara dan pemerintah bebas memberi lesen kepada sesiapa sahaja atau syarikat yang ingin menggunakan tanah itu.

Sejak perluasan permit lokasi untuk pembangunan kebun kelapa sawit kepada syarikat PT. BRS pada tahun 2006. Syarikat telah membayar sebanyak 28 orang mulai tahun 2007 hingga 2008 ke atas kerugian pokok-pokok getah masyarakat yang dipotong oleh syarikat, sebab pokokpokok getah yang telah ditanam termasuk dalam kawasan tanah perladangan syarikat (dalam dokumen senarai pampasan, 2010). Walaupun syarikat telah memberi pampasan kepada masyarakat, perkara ini masih menjadi konflik kerana masih ramai ratusan masyarakat yang tidak mendapat pampasan. Syarikat juga telah menjanjikan kebun plasma seluas dua hektar yang diutamakan untuk masyarakat yang tidak mendapat kerugian dan juga yang mendapat kerugian, tetapi mereka mengutamakan masyarakat yang tidak mendapat pampasan untuk dibahagikan kepada kebun plasma.

"ada ganti rugi imbas tebang dari perusahaan kepada masyarakat yang lebih dulu membuat kebun di sana... sekitar 750.000 rupiah/hektar, ...bibit pun tak diganti."

(Encik Mulyadi, Sabawaihi, Surya Darma, 2019)

Dari petikan tokoh masyarakat di atas, ini menjadi persoalan ketika syarikat memberi pampasan kepada masyarakat dengan harga yang sangat murah dalam Rp. 750.000 (RM220) tiap 1 hektar tanahnya. Jadi, masyarakat berpendapat syarikat hanya membayar upah pemilik yang sudah membersihkan pokok-pokok getah yang sudah ditanamnya di kawasan yang menjadi perladangan syarikat. Masyarakat juga masih beranggapan bahawa tanah itu adalah hak milik peribadi dan syarikat belum membayar kerugian benih pokok getah serta sewa tanah mengikut tempohnya.

"masyarakat ini terima ganti rugi imbas tebang tetapi tidak menerima ganti rugi tanah yang diserahkan ke perusahaan. Surat ganti rugi ini menimbulkan keraguan bahwa hanya ganti rugi membersihkan kebun saja yang diberi dan bukanlah ganti rugi tanah."(Encik Raja Fahrozi, 2019)

Petikan pegawai agensi perkebunan di atas menjelaskan, bagi syarikat pemberian pampasan bermaksud membayar upah membersihkan ladang. Syarikat berpendapat mereka tidak diwajibkan menyewa/membeli tanah masyarakat kerana tanah itu berstatus milik negara. Terdapat perbezaan persepsi mengenai konsep tanah antara masyarakat dengan syarikat. Persoalan lain juga ditemui bahawa dalam dokumen keterangan pembayaran pampasan yang diperoleh pengkaji, tidak ada ayat yang tertulis dan menjelaskan perjanjian syarikat yang mana syarikat berjanji akan memberikan 2 hektar kebun plasma yang termasuk dalam pampasan (dalam dokumen surat keterangan ganti rugi, 2007). Syarikat juga sudah menetapkan jumlah 
kerugian kepada masyarakat tanpa mengadakan mesyuarat dengan ketua kampung, tokoh masyarakat, dan masyarakat lainnya.

"ada beberapa masyarakat yang kami ganti-rugi ...mengenai jumlah ganti-rugi

berbeda-beda sesuai dengan umur tanaman..." (Encik Andri, 2019)

Menurut pegawai syarikat mengakui beberapa masyarakat sudah diberikan pampasan dan mengenai pemberian jumlah wang pampasannya berbeza-beza, mengikut kepada umur pokok getah yang telah ditanam oleh masyarakat. Menyiasat kepada beberapa dokumen (senarai nama ganti rugi, 2010) pembayaran pampasan masyarakat yang diperoleh pengkaji. Pengiraan jumlah ganti rugi ditetapkan sebanyak 750.000 rupiah untuk setiap keluasan satu hektar dan bukan mengikut umur pokok getah, ini berlaku kepada semua masyarakat. Masyarakat mengaku bahawa ganti rugi oleh syarikat ini tidak berbaloi dan merugikan mereka. Lebih-lebih lagi merugikan masyarakat yang tidak mendapat pampasan kerana plasma yang menjadi perjanjian syarikat hingga masa kini masih belum dibangunkan oleh syarikat.

\section{Konflik pembangunan perladangan syarikat yang mengambil tanah masyarakat sekitar}

Menerusi akhbar pada 13 Mac 2016, DPRD Indragiri Hulu (Legislatif Daerah) telah memberi tindak balas tentang laporan pengurusan koperasi dengan melakukan pemeriksaan langsung kepada syarikat oleh ketua suruhanjaya II DPRD untuk mengetahui kebenaran laporan daripada koperasi dan termasuk juga kewajipan yang harus dijalankan syarikat kepada daerah seperti pembayaran pajak dan penyelesaian bayaran pengambilalihan hak tanah. Perkara ini sangat penting kerana berkait rapat dengan ekonomi masyarakat tempatan secara amnya dan juga pendapatan kerajaan tempatan untuk daerah Inderagiri Hulu. Selepas berjaya untuk berjumpa, akhirnya satu perjumpaan diadakan di bilik mesyuarat asrama syarikat.

"...banyak lahan warga yang sudah diambil perusahaan tanpa sepengetahuan pemiliknya, karena perusahaan menggarapnya pada malam hari sehingga menghilangkan batas-batas lahan masyarakat." (ketua suruhanjaya II legislatif daerah, 2016)

Menurut petikan ahli DPRD di atas, ia mendapati perkara yang diperoleh bahawa tanah yang diambil syarikat banyak tanpa pemberitahuan kepada pemiliknya sebab syarikat mengerjakan ladang pada malam hari sehingga juga menghilangkan sempadan tanah masyarakat.

"total perkebunan itu tidak pernah diukur ulang... bisa saja bertambah pembukaan lahan di sana habis-habisan ...pernah menggeser kebun orang malam hari ...datanglah orangnya mengamuk dan membacok si Sam yang bekerja dan menggarap kebun inti." (Encik Edi Suhardi, 2019)

Beberapa pemimpin masyarakat telah mengakui kebenarannya seperti ketua kampung Baturijal Hulu 2007-2013 menjelaskan bahawa banyak tanah yang dikerjakan telah menjadi ladang syarikat dalam jumlah 2000 hektar lebih tanah. Jumlah keluasan perladangan utama 
syarikat itu tidak pernah diukur berkala dan boleh terus berkembang. Pembukaan ladang di sana sememangnya keterlaluan, seperti mencerobohi ladang masyarakat pada waktu malam tanpa kebenaran. Ini mengakibatkan masyarakat mengamuk dan memukul orang yang mengerjakan ladang syarikat itu. Masyarakat di kawasan sekitar juga datang mengadu dengan membawa parang bahawa ladang mereka dicerobohi masuk oleh syarikat. Sebenarnya, penyelesaian persempadanan tanah menggunakan kaedah pemetaan digital seperti GPS (global positioning system) dan sistem maklumat geografi (geographic information system-GIS) (dalam Abdul Manaf et al., 2014) telah berjaya mengelakkan isu berkenaan persempadanan tanah ini. Perkara ini boleh menjadi satu penyelesaian bagi masyarakat adat untuk merekodkan sempadan tanahnya menggunakan pemetaan digital.

\section{Implikasi Kajian}

Kerap kali pembinaan plasma belum boleh dipastikan dan belum menjadi tumpuan, inilah sebab konflik seperti pembangunan plasma yang tidak wujud seluas $20 \%$ dari perladangan syarikat, corak berkongsi keuntungan syarikat, ketersediaan tanah terhad serta kurangnya komunikasi dengan masyarakat. Justeru dalam kajian ini menemukan banyak persoalan dan kes yang terjadi dalam satu lembaga koperasi sebagai tempat berkongsinya masyarakat dengan syarikat. Pengkaji menemukan persoalan yang terjadi di dalam koperasi dalam konflik perladangan inti-plasma di Indonesia. Pertama, penyelidik melihat ada kes dalam pembuatan senarai calon petani plasma yang dibuat berasaskan kepentingan pengurusan koperasi. Perkara ini dilihat dengan menelusuri dan menyiasati cara pengurusan koperasi dari masa ke semasa. Kedua, kes rasuah atau penyalahgunaan dalam mengurus pembahagian keuntungan daripada syarikat. Ketiga, kes penggantian kepengurusan koperasi yang berlaku demi memperoleh kepentingan peribadi. Ketiga-tiga kes ini adalah yang paling terdedah dalam konflik perkongsian masyarakat dengan syarikat.

Berdasarkan hasil kajian di atas, satu konflik perkongsian kebun inti syarikat dan plasma masyarakat yang terjadi adalah mengenai perbezaan pandangan pengurusan koperasi kedua tempoh 2012-2014 berkenaan dengan pengiktirafan lokasi kebun plasma masyarakat yang harus terletak di ladang syarikat. Perkara ini sangat bertentangan dengan syarikat dan secara tidak langsung telah membawa kepada konflik baharu iaitu konflik koperasi kepada masyarakat. Kebanyakan masyarakat tidak lagi mempercayai pengurus koperasi itu kerana tanah yang telah dikemukakan oleh masyarakat untuk kebun plasma harus dibatalkan kerana terdapat perbezaan kebenaran dalam hal lokasi kebun plasma. Sementara kini pengurus koperasi 2012-2014 juga tidak mahu digantikan sehingga beliau tidak menyerahkan dokumen berkenaan kesahihan koperasi yang diperlukan pengurus baharu yang ketiga. Justeru, kesan dari konflik pengiktirafan lokasi kebun plasma itu juga telah membuat syarikat tidak perlu bersusah payah untuk membina kebun plasma dengan betul kerana terdapatnya masalah dalam koperasi sebagai badan perkongsian antara masyarakat dengan syarikat. Konflik lain koperasi kepada masyarakat iaitu pengurus koperasi kedua juga turut melakukan rasuah dalam perkara penggunaan pembahagian keuntungan daripada syarikat sebanyak 20 peratus, yang gunanya diperuntukkan kepada petani plasma. Kedua-dua konflik ini boleh dijadikan bukti kukuh kepada syarikat untuk tidak memberikan hak masyarakat selama bertahun-tahun. 


\section{Kesimpulan}

Kajian ini cukup menjelaskan tentang kewujudan konflik-konflik yang telah terjadi antara masyarakat adat dan pelabur perladangan. Perkongsian yang dilakukan antara masyarakat dengan syarikat sebagai bentuk tanggung jawab sosial syarikat kepada masyarakat telah mengalami banyak konflik. Pelbagai konflik yang terbentuk dalam perkongsian ini di antaranya adalah konflik yang terjadi secara horizontal iaitu konflik yang berada dalam koperasi seperti pembuatan senarai petani plasma yang menguntungkan peribadi pengurus koperasi kedua, penyalahgunaan atau rasuah wang pembahagian daripada syarikat dan perebutan pengurusan koperasi, sementara konflik yang terjadi secara vertikal iaitu konflik ketidakseriusan syarikat membina kebun plasma masyarakat, konflik pemberian pampasan yang tidak berbaloi dan konflik pembangunan perladangan syarikat yang banyak mengambil tanah masyarakat sekitar.

\section{Penghargaan}

Penghargaan diberikan kepada Geran Galakan Penyelidikan (GGP-2017-048) yang telah membiayai sebahagian daripada urusan penyelidikan ini.

\section{Rujukan}

Abdul Manaf, A., K, S. A., MS, S., Lyndon, N., R, Z., Saad, S., .. Mat Jali, M. F. (2015). Sempadan dan pertikaian pemilikan tanah adat di Sarawak Boundaries and customary land ownership disputes in Sarawak. Geografia-Malaysian Journal of Society and Space, 11(7), 92-103.

Abdul Manaf, A., Lyndon, N., Selvadurai, S., Hussain, M. Y., Ramli, Z., Md Sum, S., ... Mat Jali, F. (2014). Menangani cabaran tranformasi tanah NCR: satu keperluan terhadap pendekatan pemetaan berpenglibatan. Geografia-Malaysian Journal of Society and Space, 10(1), 110-117.

Anwar Tanjung, C. (2017). Luas Kebun Sawit Haram di Riau mencapai 1.8 Ha. DetikNews. Retrieved from http://news.detik.com/berita/d-3435527/luas-kebun-sawit-ilegal-di-riaumencapai-18-juta-ha

Arkanudin, \& Rupita. (2020). Etnografi Konflik Masyarakat Batu Daya dengan Perusahaan PT. Swadaya Mukti Prakarsa di Simpang Dua, Ketapang, Kalimantan Barat. MuharrikJurnal Dakwah Dan Sosial, 3(1), 18-34.

Chrisnawan, B. (2016). Peran Pemerintah Daerah dalam Mencegah Terjadinya Konflik Horizontal dalam Usaha Perkebunan Kelapa Sawit (Studi di Kabupaten Ketapang). Jurnal Nestor Magister Undang-Undang, 1(1), 1-18.

Chua, Y. P. (2012). Mastering Research Methods. Kuala Lumpur: McGraw-Hill Education.

Creswell, J. . (1998). Qualitative Inquiry And Research Design: Choosing Among Five Traditions. London: SAGE Publications.

Creswell, J. W. (2003). Research design: Qualitative, quantitative, and mixed method Approaches (Second Edi). California: SAGE Publications.

Effendi, M., Arif Nasution, M., Hamdani Harahap, R., \& Amin, M. (2018). Role of Customary Institution in Conflict Resolution of The Rights on Customary Communal Land (Study 
on Communal Land Conflict in Simangambat Jae Village Simangambat District of Padang Lawas Utara Regency). In Proceedings of the 2nd International Conference on Social and Political Development (ICOSOP 2017) (Vol. 136, pp. 37-43). Atlantis Press. https://doi.org/10.2991/icosop-17.2018.7

Heriyanto, H. (2018). Thematic Analysis sebagai Metode Menganalisa Data untuk Penelitian Kualitatif. ANUVA, 2(3), 317-324. https://doi.org/10.14710/anuva.2.3.317-324

Kospa, H.S.D. (2016). Konsep perkebunan kelapa sawit berkelanjutan. Jurnal Tekno Global, $5(1)$ $1-10$.

Retrieved

from http://ejournal.uigm.ac.id/index.php/TG/article/download/223/ 228

Mutolib, A., Yonariza, Mahdi, \& Ismono, H. (2015). (Agrarian Conflict and Communal Land Release: A Case Study of Melayu Tribe in Forest Management Unit Dharmasraya, West Sumatra). Jurnal Penelitian Sosial Dan Ekonomi Kehutanan, 12(3), 213-225. https://doi.org/10.20886/jpsek.2015.12.3.213-225

Rahman, E., Syam, J., \& Mardan. (2013). Tiga Lorong: teguh berdiri di tengah persimpangan riuh ramai. Pekanbaru: UNRI Press.

Setyawan, A. D. (2012). Konflik kepentingan berkaitan permasalahan ekologi, ekonomi dan sosio-budaya di Tanah Tinggi Dieng, Indonesia (Conflicts of interest among stakeholders involving ecology, economy and socio-culture of the Dieng Plateau, Indonesia). Geografia - Malaysian Journal of Society and Space, 8(4), 88-104.

Sobri. (2017). Konflik Agraria antara Masyarakat dengan Perusahaan Pemegang HPHTI di Kabupaten Pelalawan. Jurnal Krimonologi, 2(1), 36-50.

Surono, A. (2016). Collaborative (Partnership) As a Form of "Restorative Justice" in Conflict Resolution Forest Resources Management. Jurnal Dinamika Hukum, 16(3), 332-340. https://doi.org/10.20884/1.jdh.2016.16.3.648

Thomas, Sikwan, A., \& Rahmaniah, S. E. (2015). Konflik Sosial antara Perusahaan Perkebunan Sawit PT. Borneo Ketapang Permai dengan Masyarakat Desa Semayang Kecamatan Kembayan, Kabupaten Sanggau. Jurnal Program Magister Ilmu Sosial Universitas Tanjungpura, 2(2), 1-9.

Yin, R. K. (1989). Case Study Research: Design and Methods. Washington: COSMOS Corporation.

Yunus, H. M. (2013). Konflik Pertanahan dan Penyelesaiannya Menurut Adat di Provinsi Riau. Menara, 12(1), 23-40. 